\title{
Dopamine 2 and Somatostatin 1-5 Receptors Coexpression in Clinically Non-Functioning Pituitary Adenomas
}

\author{
F. GABALEC ${ }^{1}$, M. DRASTIKOVA ${ }^{2}$, T. CESAK ${ }^{3}$, D. NETUKA ${ }^{4}$, V. MASOPUST ${ }^{4}$, \\ J. MACHAC ${ }^{5}$, J. MAREK ${ }^{6}$, J. CAP $^{1}$, M. BERANEK ${ }^{2}$
}

${ }^{1}$ Fourth Department of Internal Medicine - Hematology, ${ }^{2}$ Institute of Clinical Biochemistry and Diagnostics, ${ }^{3}$ Department of Neurosurgery, University Hospital Hradec Kralove and Charles University in Prague, Faculty of Medicine in Hradec Kralove, Czech Republic, ${ }^{4}$ Department of Neurosurgery, First Faculty of Medicine, Charles University in Prague and Central Military Hospital Prague, Czech Republic, ${ }^{5}$ Department of Neurosurgery, University Hospital, Olomouc, Czech Republic, ${ }^{6}$ Third Department of Medicine, First Faculty of Medicine, Charles University in Prague, Czech Republic

Received May 2, 2014

Accepted October 8, 2014

On-line December 22, 2014

\section{Summary}

This study investigated quantitated expression of dopamine 2 receptor (D2R) and somatostatin receptors of the five types (SSTR1-SSTR5) in a large series of clinically non-functioning pituitary adenomas (CNFAs). Co-expression of these receptors in individual adenomas was studied as well as correlation between receptor types. Adenoma tissue from 198 patients who underwent surgery for CNFAs was analyzed by immunohistochemistry and quantitative real-time PCR. D2R and SSTR1-3 mRNA was expressed in all 198 adenomas. SSTR4 and SSTR5 were detectable in $85 \%$ and $61 \%$ of adenomas, respectively. Expression of D2R was significantly higher than that of the somatostatin receptors. The median relative expressions were as follows from highest D2R >> SSTR3 > SSTR2 $>$ SSTR1 > SSTR5 > SSTR4. High relative expression (ratio to $\beta$-glucuronidase mRNA $>1$ ) of $D 2 R$ was found in $60 \%$ of tumors, high expression of SSTR1 in $7.5 \%$, SSTR2 in $7 \%$, SSTR3 in $4 \%$ and SSTR5 in $0.5 \%$. The quantity of D2R correlated positively with expression of SSTR2 and SSTR3, and negatively with SSTR1 and SSTR5. Among histological adenoma types, SSTR1 was significantly higher in null-cell adenomas and SSTR3 was lower in silent corticotroph adenomas. In conclusions, in CNFAs, high expression of somatostatin receptors is much less common than that of $\mathrm{D} 2 \mathrm{R}$, and co-expression of both these receptors is exceptional. D2R and SSTR3 seem to be the most promising targets for pharmacological treatment.

\section{Key words}

Dopamine receptor • Somatostatin receptor • Estrogen receptor • Clinically non-functioning adenomas - Pituitary adenomas • Immunohistochemistry • Real-time PCR

\section{Corresponding author}

M. Beranek, Institute of Clinical Biochemistry and Diagnostics, University Hospital Hradec Kralove, Sokolska 581, 50005 Hradec Kralove, Czech Republic. E-mail: beranek@lfhk.cuni.cz

\section{Introduction}

Clinically non-functioning pituitary adenomas (CNFAs) represent one third of human pituitary tumors. An estimated prevalence of all pituitary tumors is $16.7 \%$ (Ezzat et al. 2004). Diagnosis of CNFAs is often determined when the tumor had grown to the stage of macroadenoma and presents with signs of mass effect. The majority of CNFAs produce either low, nonsignificant amounts of hormones or defective hormones. No more than $10 \%$ of CNFAs are immunohistochemically negative; these are called nullcell adenomas (Jaffe 2006). Transsphenoidal surgery is the primary option for CNFAs requiring treatment. However, because of frequent supra- or parasellar extension, surgery is infrequently curative, leaving tumor 
remnants that regrow in $12-58 \%$ of patients within 5 years of follow-up (Greenman et al. 2003, Brochier et al. 2010). The only independent predictors for tumor regrowth are: a) preoperative presence of cavernous sinus invasion, and b) postoperative suprasellar extent of residual tumor (Greenman et al. 2003). In postoperative management of patients, there is no clear strategy. We can choose between reoperation, Leksell-gamma knife surgery or pharmacological treatment. Each option has its drawbacks. The presence of somatostatin (SSTR) and dopamine 2 subtype (D2R) receptors in CNFAs has been proved by several methods including radioligands, in situ hybridization, RT-PCR, and quantitative real-time RT-PCR. However, empirical use of dopamine agonists (DA) or somatostatin analogues (SA) alone or in combination has been effective in only a few cases (Colao et al. 2008). Recently, new chimeric compounds "dopastatins" showed promising efficacy in vitro (Florio et al. 2008). In contrast, pharmacological treatment of CNFAs has not been successful. Highly variable expression or homo/heterodimerization of receptors in the pituitary gland partly could explain this discrepancy (Renner et al. 1998, Taboada et al. 2007, Neto et al. 2009). Thus, knowledge of receptor mRNA expression patterns would help in the targeted therapy (Babu et al. 2014). The aim of this study was to quantify coexpression of SSTR1-5 and D2R in a large series of CNFAs and to correlate the results with the pathological classification of adenomas.

\section{Patients and Methods}

Clinically non-functioning adenomas were diagnosed based on the absence of hypersecretory laboratory markers. Specifically, the IGF-I level was normal or low for the particular age, and the serum prolactin level was normal or only slightly elevated to a level considered appropriate to stalk compression seen on MRI. Urinary free cortisol was not elevated. Serum free thyroid hormones were normal or lower. Luteinizing hormone, follicle-stimulating hormone and testosterone, free testosterone (or estradiol in women) were evaluated. Diagnosis of adenoma was confirmed by pathological investigation after surgery. We enrolled 198 patients who fulfilled study criteria. Several patients from our previous analysis of D2R expression (Gabalec et al. 2012) from whom we had cDNA stored for further analysis were also included. The study was approved by the Ethics Committee; patients had all signed informed consent forms. Subjects were 113 men and 85 women, aged 15-87 years (mean \pm standard deviation $60.4 \pm 13.1$ ). All tumors except of one were macroadenomas; sized (at their largest diameters) 7-53 $\mathrm{mm}$ (mean \pm standard deviation 25.9 \pm 8.8 $\mathrm{mm}$; median: $25 \mathrm{~mm}$ ). The most common indications for operation were bitemporal hemianopsia or visual defect in 89 cases $(45 \%)$, diplopia due to nerve palsy in 26 cases (13\%), progression of tumor growth on MRI in $18(9 \%)$ and headache in $21(11 \%)$, or in $44(22 \%)$ in combination. Most patients underwent surgery by transsphenoidal endoscopic approach. Three patients needed subfrontal surgery due to the adenoma extent. At initial evaluation, hypopituitarism was present in 50 patients, diabetes insipidus in 4 cases, 26 patients had hypogonadism and only 2 subjects with hypogonadism had substitution prior to diagnosis.

\section{Pathology}

Tissue specimens were investigated as described in our previous work (Cap et al. 2003, Gabalec et al. 2012). Briefly, adenoma tissue specimens obtained at surgery were immediately fixed in $10 \%$ formalin, routinely processed, and subsequently embedded in paraffin. Sections $5 \mu \mathrm{m}$ thick were stained with hematoxylin-eosin and Goldberg's trichrome. The Gömöri silver impregnation of reticuline was used to enhance staining of fibrous tissue. In total, 133 specimens from 75 men and 58 women, aged 23-87 years (61.4 \pm 12.2 years) underwent immunohistochemical analysis. For immunohistochemistry (IHC), serial sections from the same paraffin blocks were usually exposed to a heat-mediated antigen retrieval procedure in citrate buffer, $\mathrm{pH} 6.0$, using a microwave oven. We investigated the following pituitary hormones: ACTH (monoclonal mouse antibodies, Dako, Denmark); GH; prolactin; and specific $\beta$-subunits of the dimeric glycoproteins TSH, FSH, LH, and their common $\alpha$-subunit (monoclonal antibodies, Immunotech, Prague, Czech Republic). We used the avidin-biotin technique and diaminobenzidine staining. Expression of each hormone was described semiquantitatively in 4 stages: 0 : absolutely negative; 1 : slight positivity in $<15 \%$ of cells; 2: positivity in $15-70 \%$ of cells; and 3 : strong positivity in $>70 \%$ of cells.

\section{Quantitative real-time $R T-P C R$}

Details of RNA extraction, reverse transcription and quantification were described previously (Gabalec et al. 2012). Briefly, for RT-PCR analysis, small tissue 
samples were immediately stored in RNAlater (Qiagen, Hilden, Germany) according to the manufacturer's instructions and frozen at $-80^{\circ} \mathrm{C}$ for RNA stabilization. RNA was isolated by Trizol Reagent (Invitrogen, USA) following manufacturer's instructions and transcribed to cDNA by SuperScript III First-Strand Synthesis (Invitrogen, USA). We made a real-time PCR master mix of $5 \mu 1$ of cDNA, $12.5 \mu 1$ TaqMan Universal PCR Master Mix (Life Technologies, USA), $300 \mathrm{nM}$ of each primer and $200 \mathrm{nM}$ of hydrolytic fluorescent probe. The probe and primers for D2R, SSTR1, 2, 3 and 5 were published previously (O'Toole et al. 2006). SSTR4 analyses were performed using Taqman Gene Expression Assays Hs01566620_s1 (Life Technologies, USA). After incubation for $2 \mathrm{~min}$ at $50^{\circ} \mathrm{C}$ and $10 \mathrm{~min}$ denaturation at $95{ }^{\circ} \mathrm{C}$, we performed $50 \mathrm{PCR}$ cycles of $15 \mathrm{~s}$ denaturation at $95{ }^{\circ} \mathrm{C}$ and $60 \mathrm{~s}$ annealing and elongation at $60^{\circ} \mathrm{C}$, on a Rotor-Gene 6000 (Corbett, Australia). Serial diluted plasmids pCR4 (Invitrogen, USA) with SSTR1-5 inserts (Generi Biotech, Czech Republic) were used for calibration. Taking into account RNA degradation processes, mRNA quantities were normalized to that of $\beta$-glucuronidase (GUS) housekeeping gene (Qiagen, Germany).

\section{Statistics}

mRNA quantities were expressed both absolutely, in copies per $5 \mu \mathrm{l}$ of cDNA, and relatively as the ratio of the receptor subtype to housekeeping gene copies. The distribution of values in the whole sample and by groups according to the immunocytochemical classification proved to be non-Gaussian using Kolmogorov-Smirnov test (with Lilliefors' correction). For this reason, the groups were characterized by median and percentiles and the Mann-Whitney rank sum test was used to evaluate differences between individual groups. Comparisons were also done with the use of KruskalWallis analysis of variance on ranks (Dunn's method). Correlation between various receptors expression was evaluated using Spearman Rank Order Correlation. $\mathrm{P}<0.05$ was considered significant. SigmaStat version 3.5 software (Systat Software, San Jose, USA) was used.

\section{Results}

\section{qRT-PCR analysis}

D2R and SSTR1-3 mRNA was expressed in all 198 adenomas examined. SSTR4 and SSTR5 were detectable in $85 \%$ and $61 \%$ of adenomas, respectively.
Absolute median values of mRNA expression were 1380 copies $/ \mu 1$ for SSTR1 (range: $24-1144017$ ), 4701 copies $/ \mu 1$ for SSTR2 (5-577816), 5911 copies/ $\mu 1$ for SSTR3 (1-112093), 2 copies/ $\mu 1$ for SSTR4 (0-2660), 14 copies $/ \mu 1$ for SSTR5 (0-59631) and 222075 copies/ $\mu 1$ for D2R (1-2580406). After normalization to the GUS housekeeping gene the median of relative mRNA expression was 2.34 for SSTR1, 8.26 for SSTR2, 11.38 for SSTR3, 0.01 for STSR4, 0.02 for SSTR5 and 212.20 for D2R. Expression of D2R was significantly higher than that of the somatostatin receptors. Median relative expressions were as follows from highest D2R $>>$ SSTR3 $>$ SSTR2 $>$ SSTR1 $>$ SSTR5 $>$ SSTR4 (Fig. 1).

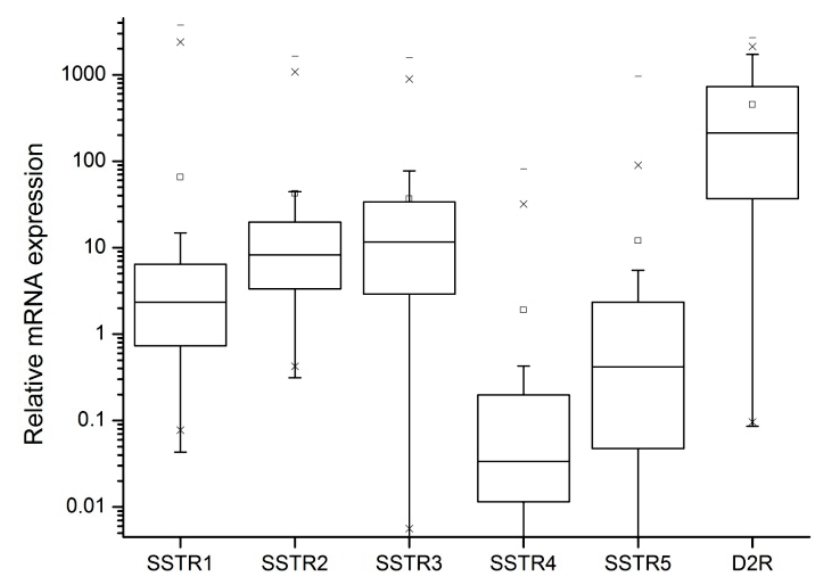

Fig. 1. Relative expression of SSTR1-5 and D2R normalized to GUS in CNFAs. Upper border of the box: $75^{\text {th }}$ percentile; lower border: $25^{\text {th }}$ percentile; line: median; whiskers: 99th percentile range; small square: arithmetic mean; crosses: extreme values.

Expression of D2R correlated positively (Correlation Coefficient 0.199, $\mathrm{P}<0.01$ ) with adenoma size. No correlation with size was found for other receptors. Receptor expression was not influenced by tumor extension.

Expression of D2R correlated positively with expression of SSTR2 and SSTR3 and inversely with expression of SSTR1 and SSTR5 (Fig. 2, Table 1). D2R expression was high (relative expression $>1$ ) in most CNFAs, whereas expression of individual somatostatin receptor types was much lower, high expression being an exception (Fig. 3).

High expression of somatostatin receptors was rare (15/198 for SSTR1, 14/198 for SSTR2, 8/198 for SSTR3 and 1/198 for SSTR5, respectively; Table 2). Coexpression of both SSTR and D2R in high quantities was even less frequent. 

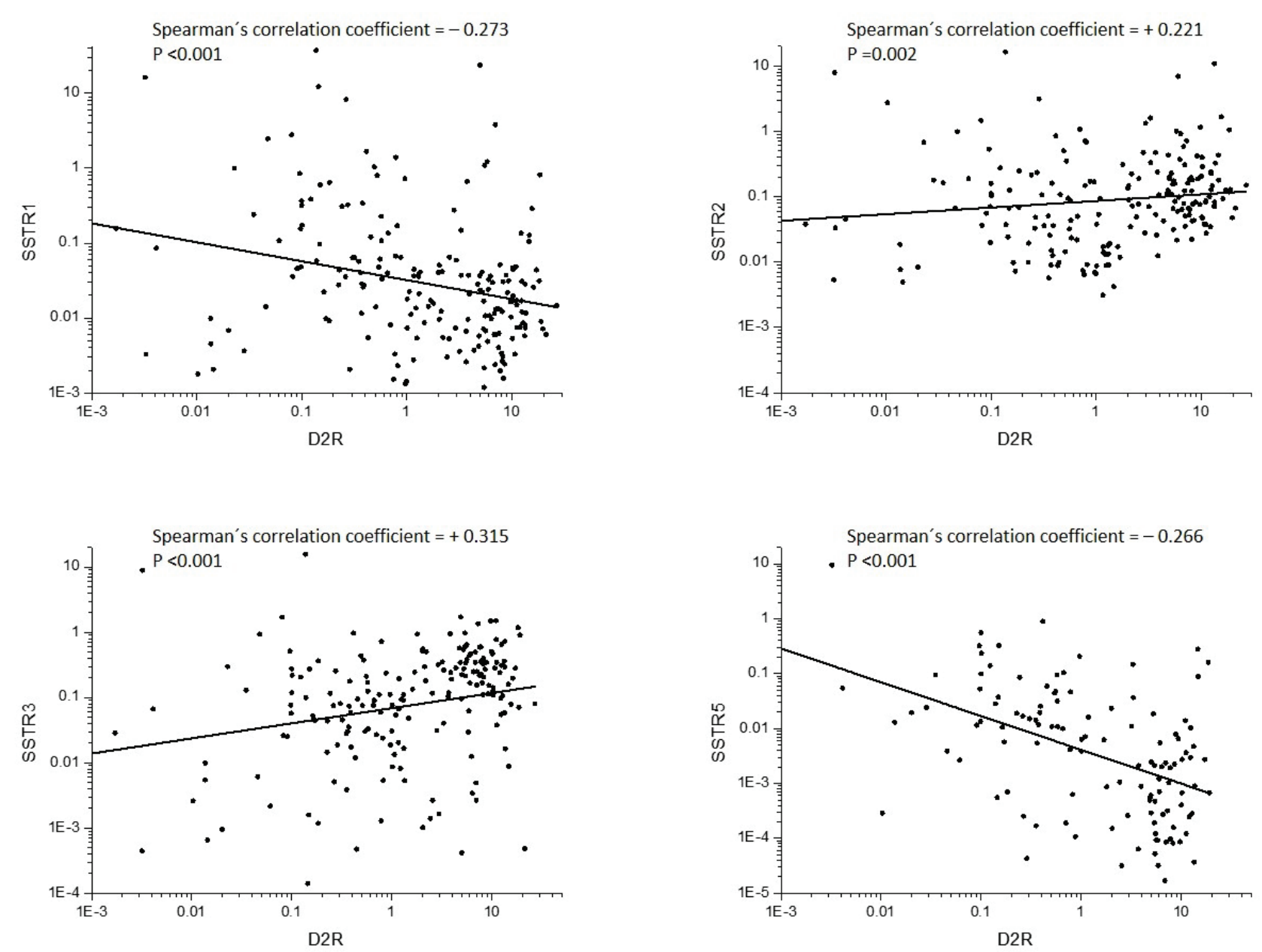

Fig. 2. Correlations of dopamine receptor (D2R) and four somatostatin receptor types relative expression. Statistical significance was established by Spearman Rank Order Correlation.

Table 1. Correlation coefficients and their significance by Spearman Rank Order Correlation.

\begin{tabular}{|c|c|c|c|c|c|}
\hline & SSTR2 & SSTR3 & SSTR4 & SSTR5 & D2R \\
\hline SSTR1 & $\begin{array}{c}0.384 \\
\mathrm{p}<0.001\end{array}$ & $\begin{array}{c}0.0393 \\
\mathrm{p}=0.583\end{array}$ & $\begin{array}{c}0.394 \\
(p<0.001)\end{array}$ & $\begin{array}{c}0.304 \\
(\mathrm{p}<0.001)\end{array}$ & $\begin{array}{c}-0.273 \\
(p<0.001)\end{array}$ \\
\hline SSTR2 & & $\begin{array}{c}0.335 \\
(\mathrm{p}<0.001)\end{array}$ & $\begin{array}{c}0.0283 \\
\mathrm{p}=0.755\end{array}$ & $\begin{array}{c}0.0245 \\
\mathrm{p}=0.732\end{array}$ & $\begin{array}{c}0.221 \\
\mathrm{p}=0.002\end{array}$ \\
\hline SSTR3 & & & $\begin{array}{c}0.026 \\
p=0.775\end{array}$ & $\begin{array}{l}-0.0159 \\
p=0.825\end{array}$ & $\begin{array}{c}0.315 \\
(\mathrm{p}<0.001)\end{array}$ \\
\hline SSTR4 & & & & $\begin{array}{c}0.289 \\
\mathrm{p}=0.001\end{array}$ & $\begin{array}{l}-0.0726 \\
p=0.424\end{array}$ \\
\hline SSTR5 & & & & & $\begin{array}{c}-0.266 \\
(p<0.001)\end{array}$ \\
\hline
\end{tabular}

qRT-PCR analysis of adenomas according to immunohistochemistry

Among 133 immunohistochemically analyzed specimens, we saw $9(6.8 \%)$ null-cell adenomas,
$103(77.4 \%) \quad$ gonadotrophs, $\quad 11(8.3 \%) \quad$ silent corticotroph tumors and $10(7.5 \%)$ plurihormonal tumors. Receptors mRNA median relative expression for different subtypes is shown in Table 3. 
The median of relative mRNA expression showed the same pattern as the complete group. In contrast, SSTR3 and D2R expressions were significantly lower in silent ACTH adenomas (Kruskal-Wallis analysis on ranks, $\mathrm{P}<0.001$ and $\mathrm{P}<0.01$, respectively). SSTR1 was expressed significantly more in null cell adenomas than in gonadotrophs (Kruskal-Wallis analysis on ranks, $\mathrm{P}<0.021$ ). Expression of SSTR1 was also higher in null cell adenomas than other subtypes, but this was not statistically significant (Fig. 4).

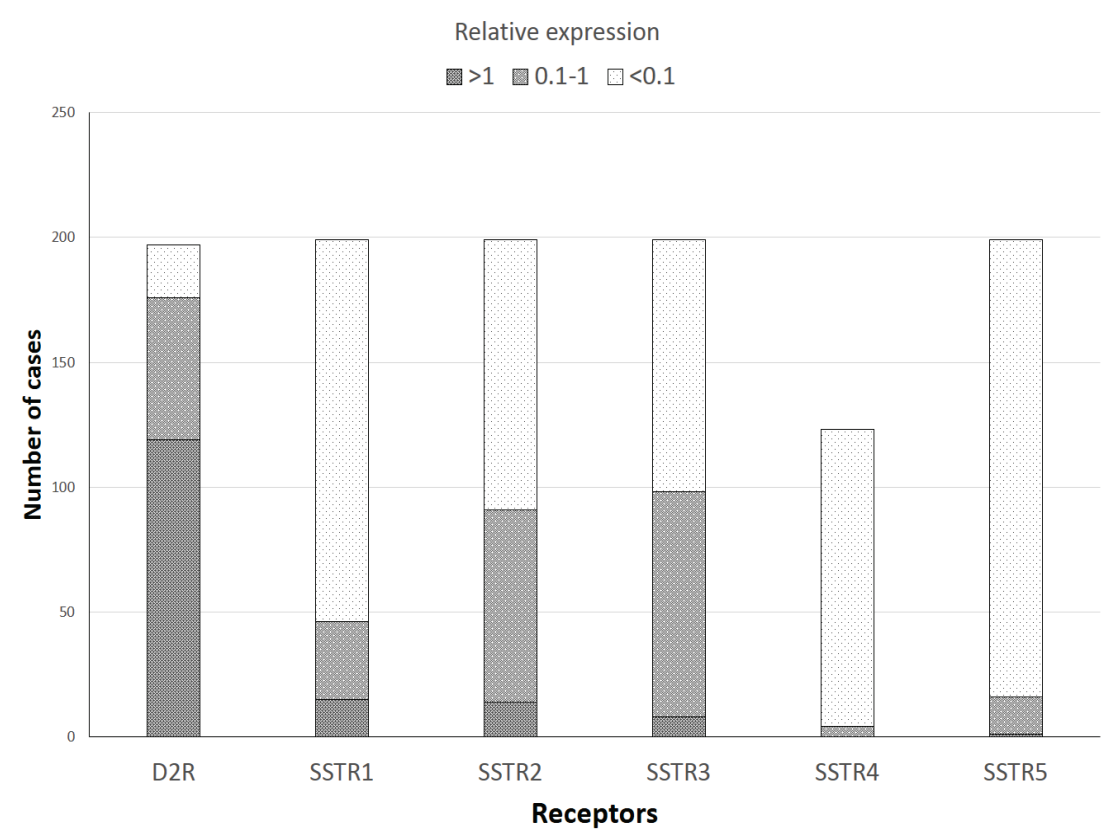

Fig. 3. Number of adenomas with high $(>1)$, medium $(0.1-1)$ and low $(<0.1)$ relative expression of individual receptors, normalized to percentage of GUS.

Table 2. Number of patients with high somatostatin receptors (relative mRNA expression/GUS $>1$ ), relative to $D 2 R$ expression ( $n=198$ adenomas).

\begin{tabular}{lcccc}
\hline & SSTR1 & SSTR2 & SSTR3 & SSTR5 \\
\hline$D 2 R / G U S>1$ & 4 & 8 & 5 & 0 \\
$D 2 R / G U S<1$ & 11 & 6 & 3 & 1 \\
Total & 15 & 14 & 8 & 1 \\
\hline
\end{tabular}

Table 3. Median SSTR1-5 and D2R mRNA expression (relative to GUS) for different adenoma subtypes.

\begin{tabular}{lcccccc}
\hline \multicolumn{7}{c}{ Median relative mRNA expression/GUS } \\
\hline SSTR1 & SSTR2 & SSTR3 & SSTR4 & SSTR5 & D2R \\
\hline Null cell adenomas & 34.00 & 12.20 & 0.50 & 0.01 & 0.00 & 134.03 \\
Gonadotrophs & 2.18 & 6.55 & 11.09 & 0.00 & 0.02 & 109.10 \\
Silent ACTH & 2.77 & 4.53 & 0.99 & 0.00 & 1.90 & 2.01 \\
Plurihormonal & 4.35 & 3.81 & 24.06 & 0.00 & 0.00 & 13.70 \\
\hline
\end{tabular}

\section{Discussion}

Transsphenoidal surgery is a standard approach to treating CNFAs. However, management of postoperative residual tumor is controversial. Dopamine agonists are a possible treatment option, as CNFAs express dopamine receptors. Greenman et al. (2005) treated 33 patients with residual tumor after surgery. Tumor remnants volumes decreased in 11 cases after DA treatment, but D2R expression was not determined. 


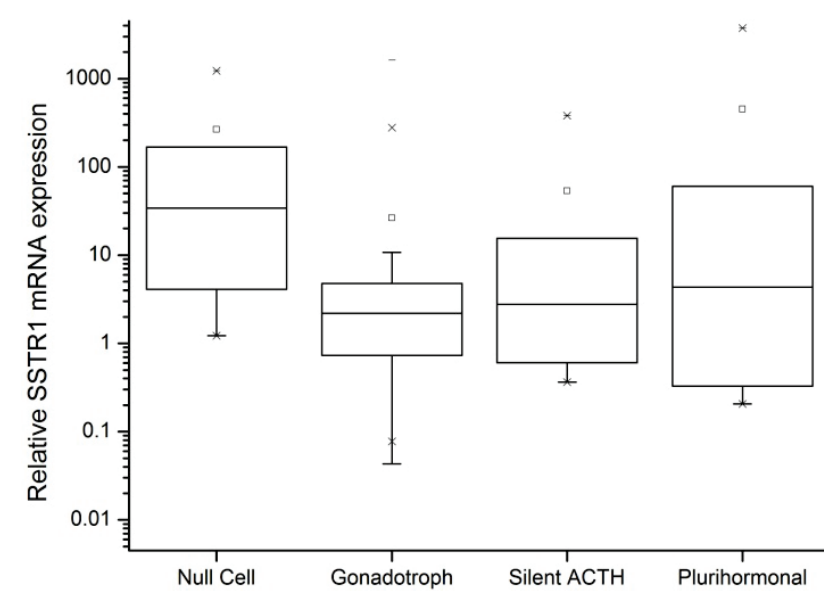

Fig. 4. Relative expression of SSTR1R normalized to GUS in individual CNFA pathology types. Null-cell adenomas and gonadotrophs differed significantly ( $\mathrm{P}=0.021$ ).

Pivonello et al. (2004) proved that tumor shrinkage after DA treatment correlates with D2R expression. Results of treatment with DA in CNFAs were reviewed by Colao et al. (2008). Cumulative evidence for tumor shrinkage in CNFAs after treatment with DA was $27.6 \%$. This is in agreement with the finding that about 20-25\% CNFAs express D2R in relatively high quantities ( $\mathrm{Su}$ et al. 2012). High variability in dopamine 2 receptor expression (in agreement with other studies (Neto et al. 2009) also concords with our work (Gabalec et al. 2012).

SSTR1, SSTR2, SSTR3 and SSTR5 are expressed in pituitary adenomas and in normal pituitary tissue. In comparison, SSTR4 expression is low or missing (Taboada et al. 2007, Neto et al. 2009). The effect of somatostatin and its analogues is determined by the binding receptor. Each receptor starts different signal pathways and intracellular response (Hofland et al. 2003, Zatelli et al. 2004, Ferone et al. 2009). Treatment with somatostatin analogues in CNFAs has poor results. Data with short-acting octreotide showed tumor volume reduction only in $12 \%$, whereas most tumors remained stable (Colao et al. 2008). A study with octreotide LAR in CNFAs in vivo showed stable tumor remnants in the majority of cases and tumor volume enlargement in $19 \%$ of cases (Fusco et al. 2012). Conversely, in vitro studies with somatostatin and lanreotide showed significantly inhibited cell proliferation in CNFAs (Florio et al. 1999). In another study SA binding SSTR1, SSTR2 and/or SSTR5 inhibited cell viability and alpha-subunit secretion in vitro (Zatelli et al. 2004). In CNFAs, our work supports the findings of Taboada et al. (2007) that SSTR3 has the highest expression levels followed by SSTR2.
Other authors report predominant and highly variable expression of SSTR2 and SSTR3 (Saveanu et al. 2001, 2009, Florio et al. 2008, Tateno et al. 2009, Babu et al. 2014), but SSTR5 was not reported in these papers or had low expression. We observed SSTR5 expression in $61 \%$ of cases and SSTR1 expression in all cases, which is more than was reported by Taboada et al. (2007). However, Babu et al. (2004) reported SSTR5 expression in $82 \%$ of patients. High variability of expression together with preferential binding of current analogues to SSTR2 could explain the low efficacy of SA. To date, no studies that use qRT-PCR correlate the number of receptor copies in CNFAs with response to SA.

Coexpression of dopamine and somatostatin receptors was evaluated only in few studies. Coexpression of SSTR2, SSTR3 and D2R in most evaluated CNFAs had highly variable expression levels (Florio et al. 2008, Neto et al. 2009, Saveanu et al. 2009, Nishioka et al. 2011). In all series somatostatin receptors are expressed much less than D2 receptors (Florio et al. 2008, Neto et al. 2009, Saveanu et al. 2009). In our study D2R expression was also higher by one order than SSTR3 or SSTR2 expression. Similar data were reported by Saveanu et al. (2009) for 58 CNFAs. The same patterns of D2R and SSTR expression were also seen in CNFAs cell cultures (Florio et al. 2008). High numbers of copies in both somatostatin and dopamine receptors were seen in 3 of 17 patients in the study of Babu et al. (2014). Evidence indicates that D2R and SSTR can form heterodimers that influence their binding capacity, signalization and internalization. After heterodimerization of SSTR5 with D2R or SSTR2 with D2R, new receptors presented with new conformation, higher activities and binding capacities for both SA and DA (Rocheville et al. 2000, Baragli et al. 2007). Adenomas with high expression of somatostatin receptors are rare and those with high coexpression of both somatostatin and dopamine receptors are an exception. Therefore chimeric compound BIM-23A760 that bind both somatostatin and dopamine receptors did not inhibit cell cultures more than DA alone (Gruszka et al. 2006, Florio et al. 2008).

We found negative correlation between D2R expression and expression of SSTR1 and SSTR5, but D2R expression correlated positively with expression of SSTR2 and SSTR3. This is an original finding, different from that of Neto et al. (2009) who found no correlation in 14 CNFAs. The number of samples probably explains the discrepancy, as the relationship is not very close. Some adenomas had low D2R expression and high 
somatostatin receptor expression, especially of the 1 and 5 subtypes.

With regard to pathological subtypes of CNFAs, we found significantly lower expression of SSTR3 in silent corticotrophs. The median relative SSTR5 expression was higher than in other subtypes, but this difference was not significant. Higher SSTR5 expression was previously reported in corticotroph adenomas (de Bruin et al. 2009). Tateno et al. (2009) also reported high SSTR5 expression in corticotroph adenoma, but did not observe significant differences between silent corticotrophs and other CNFAs. SSTR5 expression was even lower than in CNFAs. Again, this discrepancy might be due to the number of examined adenomas.

To our knowledge no previous study has correlated D2R and SSTR coexpression to pathological subtype. Compared with gonadotroph and null-cell adenomas, where D2R expression was predominant and significantly higher than SSTR, SSTR3 and SSTR2 were the most expressed receptors (although not significantly) in plurihormonal adenomas and silent corticotrophs, respectively. SSTR1 was statistically more expressed in null-cell adenomas than in other subtypes. Evaluation of other subtypes is limited by small number of cases other than gonadotrophs.

To conclude, in CNFAs, high expression of somatostatin receptors is much less common than that of $\mathrm{D} 2 \mathrm{R}$, and coexpression of both these receptors is exceptional.

\section{Conflict of Interest}

There is no conflict of interest.

\section{Acknowledgements}

This work was supported by the grant SVV 260057/2014, GAUK 723912 and by the project PRVOUK P37 of the Charles University in Prague, Czech Republic.

\section{References}

BABU A, LUQUE RM, GLICK R, UTSET M, FOGELFELD L: Variability in quantitative expression of receptors in nonfunctioning pituitary macroadenomas - an opportunity for targeted medical therapy. Endocr Pract 20: 15-25, 2014.

BARAGLI A, ALTURAIHI H, WATT HL, ABDALLAH A, KUMAR U: Heterooligomerization of human dopamine receptor 2 and somatostatin receptor 2 Co-immunoprecipitation and fluorescence resonance energy transfer analysis. Cell Signal 19: 2304-2316, 2007.

BROCHIER S, GALLAND F, KUJAS M, PARKER F, GAILLARD S, RAFTOPOULOS C, YOUNG J, ALEXOPOULOU O, MAITER D, CHANSON P: Factors predicting relapse of nonfunctioning pituitary macroadenomas after neurosurgery: a study of 142 patients. Eur J Endocrinol 163: 193-200, 2010.

CAP J, CERMAN J, NEMECEK S, MAREKOVA M, HANA V, FRYSAK Z: The influence of treatment with somatostatin analogues on morphology, proliferative and apoptotic activity in GH-secreting pituitary adenomas. J Clin Neurosci 10: 444-448, 2003.

COLAO A, Di SOMMA C, PIVONELlO R, FAGGIANO A, LOMBARDI G, SAVASTANO S: Medical therapy for clinically non-functioning pituitary adenomas. Endocr Relat Cancer 15: 905-915, 2008.

DE BRUIN C, PEREIRA AM, FEELDERS RA, ROMIJN JA, ROELFSEMA F, SPRIJ-MOOIJ DM, VAN AKEN MO, VAN DER LELIJ AJ, DE HERDER WW, LAMBERTS SW, HOFLAND LJ: Coexpression of dopamine and somatostatin receptor subtypes in corticotroph adenomas. J Clin Endocrinol Metab 94: 1118-1124, 2009.

EZZAT S, ASA SL, COULDWELL WT, BARR CE, DODGE WE, VANCE ML, MCCUTCHEON IE: The prevalence of pituitary adenomas: a systematic review. Cancer 101: 613-619, 2004.

FERONE D, GATTO F, ARVIGO M, RESMINI E, BOSCHETTI M, TETI C, ESPOSITO D, MINUTO F: The clinical-molecular interface of somatostatin, dopamine and their receptors in pituitary pathophysiology. $J$ Mol Endocrinol 42: 361-370, 2009.

FLORIO T, THELLUNG S, ARENA S, CORSARO A, SPAZIANTE R, GUSSONI G, ACUTO G, GIUSTI M, GIORDANO G, SCHETTINI G: Somatostatin and its analog lanreotide inhibit the proliferation of dispersed human non-functioning pituitary adenoma cells in vitro. Eur J Endocrinol 141: 396-408, 1999. 
FLORIO T, BARBIERI F, SPAZIANTE R, ZONA G, HOFLAND LJ, VAN KOETSVELD PM, FEELDERS RA, STALLA GK, THEODOROPOULOU M, CULLER MD, DONG J, TAYLOR JE, MOREAU JP, SAVEANU A, GUNZ G, DUFOUR H, JAQUET P: Efficacy of a dopamine-somatostatin chimeric molecule, BIM23A760, in the control of cell growth from primary cultures of human non-functioning pituitary adenomas: a multi-center study. Endocr Relat Cancer 15: 583-596, 2008.

FUSCO A, GIAMPIETRO A, BIANCHI A, CIMINO V, LUGLI F, PIACENTINI S, LORUSSO M, TOFANI A, PEROTTI G, LAURIOLA L, ANILE C, MAIRA G, PONTECORVI A, DE MARINIS L: Treatment with octreotide LAR in clinically non-functioning pituitary adenoma: results from a case-control study. Pituitary 15: 571-578, 2012.

GABALEC F, BERANEK M, NETUKA D, MASOPUST V, NAHLOVSKY J, CESAK T, MAREK J, CAP J: Dopamine 2 receptor expression in various pathological types of clinically non-functioning pituitary adenomas. Pituitary 15: 222-226, 2012.

GREENMAN Y, OUAKNINE G, VESHCHEV I, REIDER G II, SEGEV Y, STERN N: Postoperative surveillance of clinically nonfunctioning pituitary macroadenomas: markers of tumour quiescence and regrowth. Clin Endocrinol (Oxf) 58: 763-769, 2003.

GREENMAN Y, TORDJMAN K, OSHER E, VESHCHEV I, SHENKERMAN G, REIDER G II, SEGEV Y, OUAKNINE G, STERN N: Postoperative treatment of clinically nonfunctioning pituitary adenomas with dopamine agonists decreases tumour remnant growth. Clin Endocrinol (Oxf) 63: 39-44, 2005.

GRUSZKA A, KUNERT-RADEK J, RADEK A, PISAREK H, TAYLOR J, DONG JZ, CULLER MD, PAWLIKOWSKI M: The effect of selective sst1, sst2, sst5 somatostatin receptors agonists, a somatostatin/dopamine (SST/DA) chimera and bromocriptine on the "clinically non-functioning" pituitary adenomas in vitro. Life Sci 78: 689-693, 2006.

HOFLAND LJ, LAMBERTS SW: The pathophysiological consequences of somatostatin receptor internalization and resistance. Endocr Rev 24: 28-47, 2003.

JAFFE CA: Clinically non-functioning pituitary adenoma. Pituitary 9: 317-321, 2006.

NETO LV, MACHADO EDE O, LUQUE RM, TABOADA GF, MARCONDES JB, CHIMELLI LM, QUINTELLA LP, NIEMEYER P JR, DE CARVALHO DP, KINEMAN RD, GADELHA MR: Expression analysis of dopamine receptor subtypes in normal human pituitaries, nonfunctioning pituitary adenomas and somatotropinomas, and the association between dopamine and somatostatin receptors with clinical response to octreotide-LAR in acromegaly. J Clin Endocrinol Metab 94: 1931-1937, 2009.

NISHIOKA H, TAMURA K, IIDA H, KUTSUKAKE M, ENDO A, IKEDA Y, HARAOKA J: Co-expression of somatostatin receptor subtypes and estrogen receptor-alpha mRNAs by non-functioning pituitary adenomas in young patients. Mol Cell Endocrinol 331: 73-78, 2011.

O'TOOLE D, SAVEANU A, COUVELARD A, GUNZ G, ENJALBERT A, JAQUET P, RUSZNIEWSKI P, BARLIER A: The analysis of quantitative expression of somatostatin and dopamine receptors in gastro-enteropancreatic tumours opens new therapeutic strategies. Eur J Endocrinol 155: 849-857, 2006.

PIVONELLO R, MATRONE C, FILIPPELLA M, CAVALLO LM, Di SOMMA C, CAPPABIANCA P, COLAO A, ANNUNZIATO L, LOMBARDI G: Dopamine receptor expression and function in clinically nonfunctioning pituitary tumors: comparison with the effectiveness of cabergoline treatment. J Clin Endocrinol Metab 89: 1674-1683, 2004.

RENNER U, ARZBERGER T, PAGOTTO U, LEIMGRUBER S, UHL E, MULLER A, LANGE M, WEINDL A, STALLA GK: Heterogeneous dopamine D2 receptor subtype messenger ribonucleic acid expression in clinically nonfunctioning pituitary adenomas. J Clin Endocrinol Metab 83: 1368-1375, 1998.

ROCHEVILLE M, LANGE DC, KUMAR U, PATEL SC, PATEL RC, PATEL YC: Receptors for dopamine and somatostatin: formation of hetero-oligomers with enhanced functional activity. Science 288: 154-157, 2000.

SAVEANU A, GUNZ G, DUFOUR H, CARON P, FINA F, OUAFIK L, CULLER MD, MOREAU JP, ENJALBERT A, JAQUET P: Bim-23244, a somatostatin receptor subtype 2- and 5-selective analog with enhanced efficacy in suppressing growth hormone $(\mathrm{GH})$ from octreotide-resistant human GH-secreting adenomas. $J$ Clin Endocrinol Metab 86: 140-145, 2001. 
SAVEANU A, JAQUET P: Somatostatin-dopamine ligands in the treatment of pituitary adenomas. Rev Endocr Metab Disord 10: 83-90, 2009.

SU Z, WANG C, WU J, JIANG X, CHEN Y, CHEN Y, ZHENG W, ZHUGE Q, WU Z, ZENG Y: Expression of dopamine 2 receptor subtype mRNA in clinically nonfunctioning pituitary adenomas. Neurol Sci 33: 275-279, 2012.

TABOADA GF, LUQUE RM, BASTOS W, GUIMARAES RF, MARCONDES JB, CHIMELLI LM, FONTES R, MATA PJ, FILHO PN, CARVALHO DP, KINEMAN RD, GADELHA MR: Quantitative analysis of somatostatin receptor subtype (SSTR1-5) gene expression levels in somatotropinomas and non-functioning pituitary adenomas. Eur J Endocrinol 156: 65-74, 2007.

TATENO T, KATO M, TANI Y, OYAMA K, YAMADA S, HIRATA Y: Differential expression of somatostatin and dopamine receptor subtype genes in adrenocorticotropin (ACTH)-secreting pituitary tumors and silent corticotroph adenomas. Endocr J 56: 579-584, 2009.

ZATELLI MC, PICCIN D, BOTTONI A, AMBROSIO MR, MARGUTTI A, PADOVANI R, SCANARINI M, TAYLOR JE, CULLER MD, CAVAZZINI L, DEGLi UBERTI EC: Evidence for differential effects of selective somatostatin receptor subtype agonists on alpha-subunit and chromogranin a secretion and on cell viability in human nonfunctioning pituitary adenomas in vitro. J Clin Endocrinol Metab 89: 5181-5188, 2004. 